\title{
Novel Way in Teaching Introductory Soil Science
}

ADIL M. WADIA', Department of Geosciences, and WILLIAM B. CLARK, Office of Academic Affairs, University of Akron Wayne College, Orrville, $\mathrm{OH}$, USA

ABSTRACT. The importance of soils is often underemphasized in introductory undergraduate geology courses, despite their relevance to students and the communities in which they live. The high agricultural productivity of United States and the economic well-being of many of its communities are dependent on the physical properties of soils, as well as agricultural practices, human and natural history, and climate. Although this could be realized through lectures and memorization, in order to achieve the metacognitive changes necessary to promote long-term understanding and behavioral change associated with resource planning and conservation, learning activities that promote a deep approach rather than a surface approach to learning must be utilized. In this way students are engaged in activities in which they are actively searching for meaning, rather than engaging in rote memorization. This paper discusses a teaching method in which the learning objectives, activities, and assessment are aligned to achieve this aim and presents evidence of its efficacy over seven years of its use.

\section{INTRODUCTION}

Soils can be defined in a variety of ways depending upon the area of interest. For instance, a geologist may consider soils as products of weathered rocks. An engineer may place greater emphasis on the physical properties of soils -- namely texture, structure, drainage, and strength. A pedologist may define soils as a natural body, comprised of unconsolidated rock fragments and organic matter in various layers, and approach soils as an object to study and understand without any particular bias. An agronomist would define soils as the unconsolidated cover of earth, composed of mineral and organic components required for plant growth (Kohnke and Franzmeier 1995).

Soils are important for various reasons. Besides obvious value in agriculture, soils play an important role in affecting the nature of a host of other human activities, including environmental resource planning and conservation; waste disposal; recreational purposes such as parks, golf courses, and camp grounds; and foundations on which to construct (Wadia 2004).

The importance of soils in introductory geology courses is not often emphasized. Typically, soils receive a cursory mention in textbooks, which cover a very small portion in chapters that include sedimentary rocks and weathering processes. At most, these

\footnotetext{
${ }^{1}$ Address correspondence to Adil M. Wadia, Department of Geosciences, The University of Akron Wayne College, 1901 Smucker Road, Orville, OH 44667. E-mail: amwadia@ uakron.edu
}

chapters mention soil profiles and factors responsible for their formation, which include climate, vegetation, topographic relief, parent material, and time (Jenny 1941). The relationship among soil forming factors is a complex interaction best summed by the equation, Soil $=f(p, c l, r, \varnothing) t$, where $p=$ parent material, $c l=$ climate, $r=$ relief, $\varnothing=$ organic material, and $t=$ time (Buol and others 2011). Nevertheless, memorization of these factors or of this equation is not likely to serve introductory or non-major undergraduate geology students well. Instead, such students need to be presented with an engaging exercise that will allow them to discover these relationships in a context that is meaningful to them.

Students enrolled in The University of Akron Wayne College, in Orrville, Ohio, are predominantly firstgeneration students who live within 25 miles of the rural campus situated on what was, until its foundation in 1972, a working farm. In fact, many fixtures from that time still remain, including a farmhouse and derelict antique farming equipment. To this date, portions of this campus on which campus buildings have not been erected are leased to area farmers.

The state soil for the State of Ohio is the Miamian silty clay loam, which covers more than 750,000 acres. These soils are fertile supporting main crops such as winter wheat, soybeans, and corn according to United States Natural Resource Conservation Service (USNRCS), United States Department of Agriculture (USDA), Ohio (Accessed 2015). Table 1 summarizes the characteristics the soil profile of typical Miamian 
soils found in Ohio. (USNRCS, USDA, Ohio. Accessed, 2015).

Agriculture is a major part of the economy in Wayne County, Ohio, within which the highest percentage of land usage is devoted to cropland and pasture (Table 2) (United States Department of Agriculture National Agricultural Statistics Service (USDA-NASS), 2007).

Wayne County, Ohio, ranks highest in the state among 88 counties in the following categories: milkdairy product from cows; fruits, tree nuts, and berries; other crops and hay; corn for silage; forage land used for all-grass sileage, greenchop, and hay and haylage; and cattle and calves, as well as third-highest in the state for total value of livestock; poultry; and for the total value of agricultural products sold.

\section{PREVIOUS WORK}

Instructors of introductory geology courses are often challenged by the competing need to introduce an experiential component into their courses and constraints imposed by the dangers and logistical challenges of introducing inexperienced students into areas containing geologically interesting features such as stream banks and outcrops (Hudak, 2003). Hudak (2003) has demonstrated that utilizing campus features as data collection models of processes such as weathering and retaining wall stability can be effective substitutes of more inspiring settings. As Hannula (2003) has shown, as long as a lab compels students to state a hypothesis, conduct observations, and make

TABLE 1

Soil Profile of the Miamian Soils Encountered in the State of Ohio

\section{Soil Horizon Depth Characteristics}

$\begin{array}{lll}\text { A } & 5-10 " & \begin{array}{l}\text { Very dark grayish brown } \\ \text { to brown silt loam or } \\ \text { loam as topsoil }\end{array} \\ \text { B } \quad 8-35 " & \begin{array}{l}\text { Brown or yellowish } \\ \text { brown subsoil layer }\end{array} \\ \text { C } & \text { B5" } & \begin{array}{l}\text { Brown or light olive } \\ \text { brown substratum; } \\ \text { slightly or moderately } \\ \text { alkaline and has a lower } \\ \text { clay content than B }\end{array}\end{array}$

data-based inferences concerning the validity of the initial hypothesis, then students will have gained experiential knowledge in the scientific method; even mundane settings such as those utilized by Hudak (2003) are useful in this regard.

Knapp et al. (2006) have implemented engaging experiential lab experiences in an institution with the advantage of local access to the Appalachian Fold. However successful, the model utilized in this instance does not generalize well to inexperienced firstsemester, first generation students, as it relies heavily on Geographic Information Systems (GIS) and statistical analysis. Clearly, this program is successful, but does it does not generalize to other students and settings without considerable adjustment.

Given the relative inexperience of The University of Akron Wayne College students with the scientific method and the local agricultural riches, it seems that the locale presents a relatively safe, natural laboratory oflocal exploration. Learning experiences emphasizing the importance of soil are relevant, not only because the proximity of farms both on and adjacent to campus allows students to take field trips in order to study soil texture, structure, composition, and organic matter, but because these factors matter to the local economy in which they live. Student engagement is enhanced, not only because soils are located near the classroom, but because it is so clear that soils matter to the country's economic strength and local livelihood.

Because of this relevance, these exercises represent optimal alignment of learning objectives, activities, and context, as described by Biggs (1999a). Given that predominance of agriculture in the local economy, relatively few of parents of students are college educated and have modeled the expected approach to problem

TABLE 2

Percentage Distribution of Land By Activity in Wayne County, Ohio (USDA-NASS, 2007)

\begin{tabular}{lc}
\hline \hline Activity & Percentage \\
\hline Cropland & 77.66 \\
Pasture & 8.98 \\
Woodland & 8.31 \\
Other Uses & 5.04 \\
\hline
\end{tabular}


solving in higher learning. It is important to select teaching methods that will encourage students to engage learning activities with an academic orientation that first generation students would be less likely to spontaneously (Biggs, 1999b). Requiring students to actively seek answers to questions discourages them from taking a passive surface approach to learning (such as memorizing and note-taking), and instead compels students to take what Marton and Säljö (1976) term as a deep approach (such as applying and theorizing). Accordingly, requiring students to apply and theorize concerning how soils play a critical role in the maintenance of their local economy and livelihood represents optimal alignment of curriculum in undergraduate teaching of geology.

\section{MATERIALS AND METHODS}

As part of the "Ice Age and Ohio" spring course offering at The University of Akron Wayne College, from 2008 to 2014, students completed a learning activity designed to actively engage them in learning, so as to encourage them to discover the importance of soils as a natural resource. Initially, students are engaged in a discussion concerning the major glacial periods affecting Ohio and their role in shaping the land, flora, and fauna observed today. Students learn that the soil that predominates locally is classified as a Miamian silty clay loam, and that a soil of this texture has much to do with both Ohio's glacial past and the present agricultural riches of Wayne County.

Silty clay loam soils formed from loess are ideal for agriculture because they hold nutrients, moisture, and humus better than sandy soils (Buol and others 2011). However, it is a combination of natural history, human history, and current practice that maintains superior productivity. Rather than simply presenting students with a list of these factors, students are asked to discover these through inductive reasoning, by way of answering a series of three questions, presented in six parts (Wadia 2011).

Through this learning activity, students attempt to answer the following questions, and arrive at the following conclusions, as learning activities and objectives, respectively:

1) Why is the agricultural productivity of soils in the United States generally better than other parts of the world (aside from the technological advances, quality of fertilizers, pesticides, etc.) considering: 1a) the duration of agricultural activities in the United States:

Objective (conclusion): The duration of farming in the United States (approximately two centuries) is considerably less than in parts of Asia and Africa, where agricultural activities span a few millennia. Therefore, the soils in the United States are much younger, fresher, and more fertile, as they have been farmed for a relatively shorter duration.

1b) the effect of the United States' winters:

Objective (conclusion): The growing season in the United States in many places (mainly the Midwest) is restricted from about April-May to SeptemberOctober. For the rest of the year, the soils are frozen, and winters give soils a break. Furthermore, snow provides a protective covering reducing soil decomposition.

1c) the historic effects of glaciation in North America:

Objective (conclusion): The Pleistocene Age (Ice Age) resulted in glaciers bringing fresh new material, which influenced the fertility of the soil, as well as the topography.

2) Why are crops rotated from season to season?

Objective (conclusion): Different crops take up as well as return different nutrients to the soil, and keep the soil at its optimum. A crop may be farmed for two consecutive years, but after that, a different crop should be planted. For instance, needed application of nitrogen is reduced when corn is planted after soybean, as compared with that required between two consecutive corn growing seasons (Schoessow and others 2010; Crops and Soils 2011).

3) After crops have been harvested, why are the stalks kept in place?

Objective (conclusion), (two part answer):

Part 1: As the stalks decay, they return nutrients back into the soil.

Part 2: The stalks are kept in place after harvest in order to reduce soil erosion, as stalks act as soil binding-tethering mechanisms.

Students were asked to prepare written answers to each of these questions outside of class. However, they were free to discuss their answers among themselves and to use whatever resources they wished, so long as they provided appropriate citations of their sources. At the conclusion of the written exercise, student responses were discussed in class; weather permitting, a field trip was also conducted to one of the farms close 
to campus, so as to reinforce the concepts that were covered in the exercise.

\section{RESULTS}

Student responses were evaluated by the instructor for accuracy and thoroughness, according to the following rubric: two points per each of the three parts of question one (soil productivity), two points for question two (crop rotation), and one point per each of the two parts of question three (leaving stalks in place). Accordingly, the greatest weight was given to responses concerning soil productivity. The merit of each of the six scored responses was evaluated separately from the other five. However, no fractional points were awarded, and one point was not awarded as partial credit either for question two, or any part of question one.

The aggregate sum of points awarded for each

TABLE 3

Summary of Results (scores and numbers of students earning that score over 2008-2014)

\section{Individual Frequency Cumulative Cumulative Student Frequency Percent (\%) Scores}

\begin{tabular}{rrrr}
\hline 10 & 47 & 47 & 33.8 \\
9 & 36 & 83 & 59.7 \\
8 & 22 & 105 & 75.5 \\
7 & 15 & 120 & 86.3 \\
6 & 8 & 128 & 92.1 \\
5 & 5 & 133 & 95.7 \\
4 & 4 & 137 & 98.6 \\
3 & 1 & 138 & 99.3 \\
2 & 1 & 139 & 100.0 \\
1 & 0 & 139 & 100.0 \\
\hline 0 & 0 & 139 & 100.0 \\
Total & 139 & 139 & 100.0 \\
\hline
\end{tabular}

semester was produced, and this was divided by the number of participating students to yield a mean term score. Conveniently, the maximum number of points awarded per student is 10 , so the resulting term score can be intuitively interpreted without further transformation. Generally, the desired benchmark for a given class is that students be able to answer these questions sufficiently so as to earn 75 percent of the total points possible. As can be seen in Figure 1, this was achieved five out of the seven semesters. In addition, at the level of the individual student, across all semesters, it can be inferred from Table 3 that more than 75 percent of the time, of all students achieve a score of eight or better. Overall, the exercise produces the added value to student learning that is expected.

Furthermore, individual comments made by student participants suggest that the exercise has the desired effect of increasing student engagement. First, some students remark that questions concerning the relative agricultural productivity of the United States versus other parts of the world are particularly challenging. Second, many commented that their internet searches for quick answers were not of much help. Finally, some students resorted to consulting individuals involved with farming. These latter instances, in which students were compelled to actively seek information in their community, represent ideal outcomes. At the least, there is compelling evidence that these exercises are prompting some students to approach problems with an academic orientation to a greater extent than they would if not for the personal and local relevance of these activities.

\section{DISCUSSION}

Soils play an important role in a number of human activities; for most University of Wayne College students, agriculture, resource planning, and

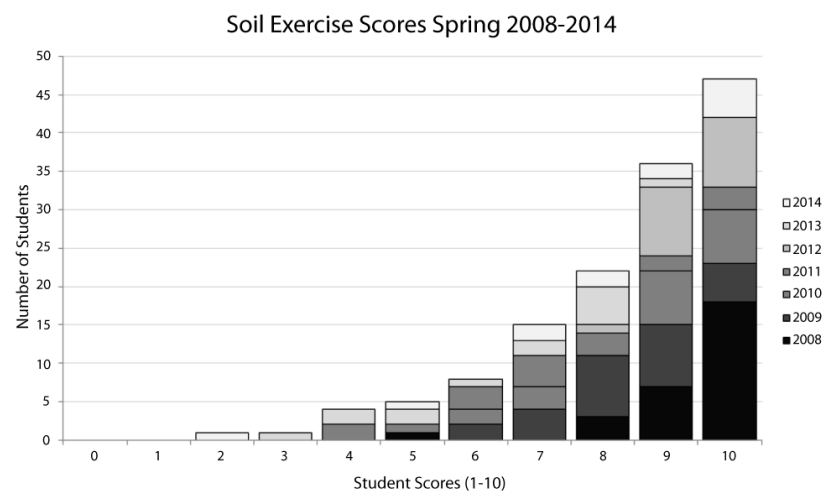

FIGURE 1. Overall summary of results. 
conservation will be paramount. However, resource planning and implementation of conservation measures, in particular, are long-term endeavors that require multigenerational commitment. Although students can be compelled to memorize a list of soil forming factors, this would do little toward developing appreciation of how these factors affect their livelihood and compelling students to consider these in their future decision making. This is because, as Biggs (2003) states, students typically second-guess coming assessment tasks and learn what they believe will meet the requirements; thus, memorization tasks will likely evoke a surface approach to learning at odds with the development of metacognitive skills necessary to practice conservation. This is increasingly problematic with students who are not prone to approaching problems with an academic orientation, and as class sizes grow larger (Biggs 2003).

Proper alignment between not only the learning objectives and learning activities, but also assessment practices, dissuades a surface approach to learning, encourages an academic approach, and promotes the development of lifelong learning (Biggs 1999b). In this exercise, students cannot simply memorize the correct answers; instead, they must seek them out through sources that they must identify, and must persist in their search until they themselves are satisfied with the answer. Further, the instructor's evaluation of the work product is not a statement of right or wrong, but of the quality of the response in terms of sufficiency of the explanation, merit of the writing, and the breadth of the resources used. Not only do students receive a score, they receive feedback, both individually and as groups. As individuals, students receive constructive feedback, as appropriate. As a group, particularly commendable efforts are discussed, in order to recognize them and to model superior work and effort. In this manner, assessment of students' work product is what Ainsworth and Viegut (2006) term as formative rather than summative. As such, the evaluative criteria reinforce the initial educational objective of learning about the impact of soils, and ultimately applying this learning.

\section{ACKNOWLEDGMENTS}

The authors would like to thank Lisa Nagy, Coordinator of Library Services at The University of Akron Wayne College for assistance in obtaining some of the journal articles used in this research.

\section{LITERATURE CITED}

Ainsworth L, Viegut, D. 2006. Common formative assessments. Thousand Oaks, CA: Corwin Press.

Biggs J. 1999a. What the student does teaching for enhanced learning. Higher Education Research \& Development, (18) 1.

Biggs J. 1999b. Teaching for quality learning at nuiversity. Buckingham, Australia: Open University Press.

Biggs J. 2003. Teaching for quality learning at university - What the Student Does 2nd Edition SRHE / Open University Press, Buckingham.

Buol SW, Southard RJ, Graham RC, McDaniel PA. 2011. Soil genesis and classification, Iowa State University Press, Ames, Iowa.

Jenny H. 1941. Factors of soil formation, New York, New York, U.S.A., London, United Kingdom. McGraw-Hill Book Company, Inc. Hudak, PF. 2003. Campus field exercises for introductory geology courses. J Geogr102:220-225.

Hannula, KA. 2003. Revising geology labs to explicitly use the scientific method. J Geosci Ed 51:194-200.

Hudak PE. 2007. Campus field exercises for introductory geoscience courses. J Geogr102:220-225.

Knapp, EP, Greer, L. Connors, CD, Harbor, J. 2006. Eield-based instruction as part of a balanced curriculum at Washington and Lee University. J Geosci Ed 54:103-108.

Kohnke H, Franzmier DP. 1995. Soil science simplified. Prospect Heights, Illinois. Waveland Press, Inc..

Marton F, Säljö, R. 1976. On qualitative differences in learning. I-Outcome and process. British J Educ Psychol 46: 4-11.

Schoessow KA, Kilian KC, Bundy LG. 2010. Soybean residue management and tillage effects on corn yields and response to applied Nitrogen. Agron J 102: 1186-1193.

Crops and Soils.March-April 2011. Effects of soybean residue management and tillage on corn yields. Crops Soils, Madison, Wisconsin, 30-36.

United States Department of Agriculture-National Agricultural Statistics Service (USDA-NASS). 2007. Census of Agriculture. Washington, DC.

United States Natural Resource Conservation Service, USDA, Ohio. Accessed 2015. http://www.nrcs.usda.gov/wps/portal/ nrcs/main/oh/soils/

Wadia AM. 2004. Classifying mollisol soils using hyperspectral remote sensing data. Terre Haute, Indiana, unpublished doctor of philosophy dissertation, Indiana State University.

Wadia AM. 2011. An innovative approach towards teaching soil science. International Annual Meeting of the American Society of Agronomy, Crop Science Society of America, and Soil Science Society of America, October 16-19, 2011, San Antonio, Texas. 